\title{
Strategi Kepemimpinan Kepala Sekolah Di Era Revolusi Industri 4.0 Berlandaskan Pada Konsep Panca Upaya Sandhi
}

\author{
I Wayan Aryawan ${ }^{1 *}$ \\ ${ }^{1}$ Program Studi Pendidikan Bahasa Indonesia dan Daerah, Universitas Dwijendra, Denpasar, Indonesia
}

\section{A R T I C L E I N F O}

Article history:

Received 14 Desember 2019

Accepted 23 Desember 2019

Available online 31

Desember 2019

\section{Kata Kunci:}

stategi kepemimpinan,

kepala sekolah,

revolusi industri 4.0,

panca upaya sandhi

Keywords:

leadership strategy,

principal,

industrial revolution 4.0,

\begin{abstract}
A B S T R A K
Terkait dengan kepemimpinan, masyarakat Hindu di Bali memilki nilai kearifan lokal yang digunakan sebagai landasan dalam menjalankan kepemimpinan yang disebut Panca Upaya Sandhi. Jika kearifan lokal ini dapat dipertahankan dan diterapkan sejalan dengan gaya kepemimpinan modern saat ini, diharapkan akan dapat mengoptimalkan kualitas kepemimpinan yang dijalankan dan juga dapat menjaga nilai-nilai yang diwariskan oleh leluhur. Tujuan dari penelitian ini adalah untuk mengetahui bagaimana strategi kepemimpinan Kepala Sekolah di era revolusi industri 4.0 berlandasakan pada konsep Panca Upaya Sandhi. Metode yang digunakan dalam penelitian ini adalah metode kualitatif. Data dikumpulkan melalui studi kepustakaan, dimana informasi diperoleh dari buku literatur, jurnal, peraturan, laporan penelitian, karangan ilmiah, media massa dan sumber-sumber tertulis baik cetak maupun elektronik. Hasil penelitian ini yaitu strategi kepemimpinan Kepala Sekolah yang dapat diterapkan di era revolusi industri 4.0 terdiri dari strategi kepemimpinan
\end{abstract} yang berorientasi pada peningkatan kualitas Sumber Daya Manusia (SDM) dan sarana dan prasana penunjang di bidang Teknologi Informasi dan Komunikasi (TIK), kepemimpinan yang terbuka, kepemimpinan yang siap menghadapi ketidak-terdugaan, kepemimpinan yang bereaksi cepat terhadap perubahan yang ada, kepemimpinan yang berorientasi pada hasil, kepemimpinan dengan formula $4 \mathrm{C}$ yaitu critical thinking, creativity, communication, collaboration, dan kepemimpinan yang mampu mengembangkan jiwa kewirausahaan. Strategi kepemimpinan ini dapat dioptimalkan dengan dilandasi filosofi Panca Upaya Sandhi yang terdiri dari Maya, Upeksa, Indra Jala, Vikrama, dan Lokika.

\begin{abstract}
A B S T R A C T
Related to leadership, the Hindu community in Bali has the value of local wisdom, which is used as a basis for carrying out leadership called the Panca Upaya Sandhi. If this local wisdom can be maintained and applied in line with the current style of new leadership, it is expected to be able to optimize the quality of leadership that is carried out and also can maintain the values inherited by the ancestors. The purpose of this research is to find out how the Principal's leadership strategy in the era of the industrial revolution 4.0 is based on the concept of the Panca Upaya Sandhi. The method used in this research is qualitative. The data were collected through library research, where the information was obtained from the literature books, journals, regulations, research reports, monographs, mass media, and written sources, both print and electronic. The results of this study are the Principal's leadership strategy that can be applied in the era of the industrial revolution 4.0 consisting of leadership strategies oriented to improving the quality of Human Resources (HR) and supporting facilities and infrastructures in the field of Information and Communication Technology (ICT), open leadership, leadership ready to face the unexpected, leadership that reacts quickly to changes, results-oriented leadership, leadership with formula $4 \mathrm{C}$ that is critical thinking, creativity, communication, collaboration, and leadership that can develop an entrepreneurial spirit. This leadership strategy can be optimized based on the philosophy of the Panca Upaya Sandhi consisting of Maya, Upeksa, Indra Jala, Vikrama, and Lokika.
\end{abstract}

Copyright (C) Universitas Pendidikan Ganesha. All rights reserved.

\footnotetext{
* Corresponding author.

E-mail addresses: aryawan@undwi.ac.id
} 



\section{Pendahuluan}

Kepemimpinan merupakan komponen yang sangat penting dalam menjalankan roda organisasi. Setiap organisasi sewajarnya mempunyai pemimpin untuk menggerakkan elemenelemen organisasi tersebut. Tanpa adanya seorang pemimpin organisasi akan kehilangan arah dalam menjalankan organisasinya. Di era revolusi industri 4.0 yang serba cepat ini diperlukan strategi yang tepat dalam menjalankan kepemimpinan sehingga tujuan yang diharapkan oleh organisasi dapat tercapai.

Kepemimpinan adalah tentang pengaturan pimpinan dan menginspirasi orang lain untuk melakukan suatu pekerjaan kepada sesuatu yang baru dan memajukan organisasi sekolah. Menurut Bush dan Marianne (Wulandari dkk, 2019) kepemimpinan di bidang pendidikan memiliki pengertian bahwa pemimpin harus memiliki keterampilan dalam mempengaruhi, mendorong, membimbing, mengarahkan, dan menggerakkan orang lain yang ada hubungannya dengan pelaksanaan dan pengembangan pendidikan dan pengajaran ataupun pelatihan agar segenap kegiatan dapat berjalan secara efektif dan efisien yang pada gilirannya akan mencapai tujuan pendidikan dan pengajaran yang telah ditetapkan. Kepemimpinan yang diharapkan adalah kepemimpinan yang berorientasi pada masa depan (transformation leadership).

Strategi adalah cara yang digunakan dalam mengerahkan semua kemampuan dari segenap sumber daya yang ada pada suatu organisasi supaya bisa bekerjasama untuk mencapai tujuan yang telah ditetapkan. Bisa dikatakan bahwa strategi merupakan faktor penentu keberhasilan suatu organisasi. Tanpa strategi, sebuah institusi tidak akan bisa yakin bagaimana bisa memanfaatkan peluang-peluang baru (Sriwahyuni, Kristiawan, \& Wachidi, 2019).

Strategi kepemimpinan kepala sekolah merupakan cara untuk mengatasi segala kendala atau tantangan dengan memanfaatkan segala sumber daya sekolah, termasuk meningkatkan profesionalisme guru untuk mencapai tujuan sekolah (Fakhrunnisa, 2019). Sedangkan menurut Yulmawati Strategi kepemimpinan kepala sekolah merupakan kegiatan mengambil keputusan atau merancangkan tindakan-tindakan strategis untuk mencapai tujuan organisasi yang ditetapkan sehingga dapat tercapai secara efektif dan efisien (Yulmawati, 2016). Implementasi dari strategi kempimpinan kepala sekolah dalam penelitian yang dilakukan oleh Suriansyah \& Aslamiah (2015) menemukan bahwa strategi yang diterapkan kepala sekolah dalam membentuk karakter siswa meliputi komunikasi falsafah, visi, misi secara jelas, keteladanan, disiplin, kepemimpinan instruksional, kepemimpinan mutu, dan pemberdayaan guru dan tenaga kependidikan. Sedangkan dalam penelitian yang dilakukan oleh Sriwahyuni, Kristiawan, dan Wachidi (2019) menemukan strategi kepala sekolah SMK Negeri 2 Bukittinggi dalam mengimplementasikan standar nasional pendidikan yaitu berbeda-beda sesuai dengan standar masing-masing. Dalam mengimplementasikan standar isi dibentuk team pengembang kurikulum berkolaborasi dengan dunia usaha dalam melakukan pengembangan kurikulum. Dalam mengimplementasikan standar proses dilaksanakan pembelajaran berbasis Information and Technology (IT). Dalam mengimplementasikan standar kompetensi lulusan dengan meningkatkan prestasi bidang akademik melalui Lomba Keterampilan Siswa (LKS), meningkatkan jumlah lulusan siap kerja dengan mengasah jiwa kewirausahaan dan kegiatan PKL. Dalam mengimplementasikan standar pendidik dan tenaga kependidikan dengan meningkatkan kompetensi pendidik dan tenaga kependidikan melalui pelatihan, dan semacamnya. Dalam mengimplementasikan standar sarana dan prasarana dengan perencanaan, pengadaan, pemeliharaan dan inventarisasi sarana dan prasarana sekolah. Dalam mengimpelementasikan standar pengelolaan dengan menyusun Rencana Kerja Sekolah (RKS) dan Rencana Kegiatan Anggaran Sekolah (RKAS), merumuskan dan mensosialisasikan visi dan misi sekolah dan menerapkan manajemen mutu ISO 9001-2008. Dalam mengimplementasikan standar pembiayaan dengan membuat perencanaan, pengelolaan dan pelaporan pembiayaan sekolah. Dalam mengimplementasikan standar penilaian dengan melakukan penilaian berbasis Information and Technology (IT). Permasalahan yang biasanya ditemui dalam penerapan strategi kepemimpinan kepala sekolah ini adalah terkait pembiayaan, komitmen dari seluruh elemen yang ada di sekolah serta sarana dan prasarana pendukung.

Tujuan pendidikan di sekolah yaitu untuk mempersiapkan peserta didik, menghasilkan manusia yang beriman dan bertakwa kepada Tuhan Yang Maha Esa, berakhlak mulia; 
mengembangkan potensi peserta didik agar menjadi masyarakat yang bertanggung jawab dan demokratis; menguasai ilmu pengetahuan dan teknologi; memiliki etos budaya kerja; dapat memasuki dunia kerja dan dapat mengikuti pendidikan lebih lanjut. Semuanya merupakan kebutuhan dasar dari peserta didik yang harus dapat dicapai (Haris, 2018).

Organisasi pendidikan baik itu pendidikan dasar dan menengah termasuk organisasi yang cukup kompleks dalam pengelolaannya. Kepala sekolah sebagai seorang pemimpin harus selalu siap dengan segala perubahan yang terjadi begitu cepat dalam dunia pendidikan. Selain itu, seorang kepala sekolah yang berkualitas harus mampu memengaruhi guru, tenaga kependidikan dan siswa yang ada pada sekolah yang dipimpinnya untuk mau menjalankan tugas-tugas di sekolah sebagai upaya pencapaian tujuan organisasi. Kompleksnya permasalahan yang ada di sekolah menuntut seorang kepala sekolah untuk berpikir visioner sehingga dapat memajukan sekolah yang dipimpinnya. Kepemimpinan visioner adalah kemampuan pemimpin untuk mencetuskan ide atau gagasan suatu visi selanjutnya melalui dialog yang kritis dengan unsur pimpinan lainnya merumuskan masa depan organisasi yang dicita-citakan yang harus dicapai dengan komitmen semua anggota organisasi melalui proses sosialisasi, transformasi, implementasi gagasan-gagasan ideal oleh pemimpin organisasi (Wahyudi, 2015).

Kepala sekolah memiliki peranan strategis dalam peningkatan mutu satuan pendidikan. Berdasarkan Permendikbud Nomor 6 Tahun 2018 tentang Penugasan Guru sebagai Kepala Sekolah, saat ini jabatan kepala sekolah bukan lagi tugas tambahan, tetapi sebagai tugas pokok. Pasal 1 ayat (1) Permendikbud Nomor 6 Tahun 2018 menyatakan bahwa "Kepala Sekolah adalah guru yang diberi tugas untuk memimpin dan mengelola satuan pendidikan yang meliputi Taman Kanak-Kanak (TK), Taman Kanak-Kanak Luar Biasa (TKLB), Sekolah Dasar (SD), Sekolah Dasar Luar Biasa (SDLB), Sekolah Menengah Pertama (SMP), Sekolah Menengah Pertama Luar Biasa (SMPLB), Sekolah Menengah Atas (SMA), Sekolah Menengah Kejuruan (SMK), Sekolah Menengah Atas Luar Biasa (SMALB), atau Sekolah Indonesia di Luar Negeri."

Permendikbud Nomor 6 Tahun 2018 menjadikan kepala sekolah penuh sebagai pemimpin dan manajer sekolah, tidak lagi dibebani tugas mengajar. Hal ini bertujuan agar kepala sekolah dapat fokus melaksanakan tugasnya untuk meningkatkan mutu sekolah. Pasal 15 ayat (1) menyatakan bahwa "Beban kerja Kepala Sekolah sepenuhnya untuk melaksanakan tugas pokok manajerial, pengembangan kewirausahaan, dan supervisi kepada Guru dan tenaga kependidikan. Sedangkan pada ayat (2) dinyatakan bahwa "Beban kerja Kepala Sekolah sebagaimana dimaksud pada ayat (1) bertujuan untuk mengembangkan sekolah dan meningkatkan mutu sekolah berdasarkan 8 (delapan) standar nasional pendidikan."

Sebagai seorang pemimpin, Kepala Sekolah harus memimpin dan memberdayakan sejumlah pendidik dan tenaga kependidikan di sekolah yang dipimpinnya untuk bersama-sama mencapai visi dan misi sekolah. Ada 5 (lima) kompetensi yang harus dimilikinya, antara lain; (1) kompetensi kepribadian, (2) kompetensi manajerial, (3) kompetensi kewirausahaan, (4) kompetensi supervisi, dan (5) kompetensi sosial.

Sebagai manajer sekolah, Kepala Sekolah harus meningkatkan mutu sekolah dalam rangka mencapai 8 (delapan) Standar Nasional Pendidikan (SNP), yang meliputi (1) Standar Kelulusan, (2) Standar Isi, (3) Standar Proses, (4) Standar Penilaian, (5) Standar Pendidik dan Tenaga Kependidikan, (6) Standar Pengelolaan, (7) Standar Sarana dan Prasarana, (8) Standar Pembiayaan.

Ada beberapa hal yang dikelola oleh kepala sekolah sebagai seorang manajer, antara lain, (1) pengelolaan kurikulum, (2) pengelolaan pendidik dan tenaga kependidikan, (3) pengelolaan kesiswaan, (4) pengelolaan sarana dan prasarana, (5) pengelolaan keuangan, (6) penerimaan peserta didik baru, (7) pengelolaan lingkungan sekolah, dan sebagainya.

Merujuk kepada uraian tersebut di atas, maka tugas seorang kepala sekolah memang cukup berat. Walaupun demikian, seorang kepala sekolah yang memiliki visi yang jelas, tentunya akan berupaya sekuat tenaga untuk memimpin dan mengelola sekolah dengan sebaik-baiknya. Terlebih lagi saat ini telah memasuki era revolusi industri 4.0, era dimana teknologi informasi dan komunikasi (TIK) dimanfaatkan sepenuhnya dihampir semua lini kehidupan manusia. Perkembangan pendidikan di dunia saat ini tidak lepas dari adanya perkembangan dari revolusi industri yang terjadi di dunia, karena secara tidak langsung perubahan tatanan ekonomi turut 
merubah tatanan pendidikan di suatu negara. Menurut Kasali (2018) Revolusi industri 4.0 ini sering juga disebut sebagai Era Disrupsi, Era Inovasi atau juga disebut sebagai Ancaman bagi incumbent (Rusdianto, 2019).

Konsep revolusi industri 4.0 ini merupakan konsep yang pertama kali diperkenalkan oleh Profesor Klaus Schwab. Beliau merupakan ekonom terkenal asal Jerman sekaligus penggagas World Economic Forum (WEF) yang melalui bukunya, The Fourth Industrial Revolution, menyatakan bahwa revolusi industri 4.0 secara fundamental dapat mengubah cara kita hidup, bekerja, dan berhubungan satu dengan yang lain. Richard Mengko, yang mengutip dari A.T. Kearney dalam Stevani Halim, menggambarkan empat tahap revolusi industri. Pertama, Revolusi industri yang pertama terjadi pada akhir abad ke-18. Hal ini ditandai dengan ditemukannya alat tenun mekanis pertama pada tahun 1784. Kedua, Revolusi industri 2.0 terjadi di awal abad ke20. Kala itu ada pengenalan produksi massal berdasarkan pembagian kerja. Ketiga, Awal tahun 1970 ditengarai sebagai perdana kemunculan revolusi industri 3.0 yang dimulai dengan penggunaan elektronik dan teknologi informasi guna otomatisasi produksi. Terakhir, 2018 hingga sekaranglah zaman revolusi industri 4.0. Industri 4.0 adalah industri yang menggabungkan teknologi otomatisasi dengan teknologi cyber. Ini merupakan tren otomatisasi dan pertukaran data dalam teknologi manufaktur. Pada era ini, industri mulai menyentuh dunia virtual, berbentuk konektivitas manusia, mesin dan data, semua sudah ada di mana-mana, atau dikenal dengan istilah Internet of Things (IoT) (Mukhlasin, 2019).

Pesatnya perkembangan teknologi pada era revolusi industri 4.0 ini harus diimbangi pula dengan memperkuat keimanan dan ketaqwaan kepada Tuhan Yang Maha Esa. Sebagai bangsa yang percaya dengan keberadaan Tuhan, disamping memperdalam pengetahuan dan teknologi hendaknya tetap berpegangan pada ajaran-ajaran atau konsep-konsep agama yang merupakan warisan leluhur/nenek moyang. Ajaran-ajaran/konsep-konsep tersebut pada prinsipnya merupakan rambu-rambu/pedoman atau tuntunan sehingga secepat apapun perkembangan teknologi dapat dijalankan dengan bijak dan tidak kebablasan. Terkait dengan itu, dalam ajaran agama Hindu juga dikenal konsep-konsep ilmu kepemimpinan yang dapat disinergikan dengan gaya kepemimpinan modern saat ini. Konsep-konsep kepemimpinan dalam ajaran Hindu antara lain: Catur Pariksa, Astabrata, Pancadasa Paramiteng Prabhu, Sadvarnaning Nrpati, Panca Upaya Sandhi, dan Nawa Natya (Latra, 2017).

Panca Upaya Sandhi berasal dari tiga kata yakni Panca yang berarti Lima, Upaya yang berarti akal, atau usaha dalam hal ini jalan keluar suatu persoalan dan Sandhi yang artinya kode, rahasia atau berita. Jadi Panca Upaya Sandhi dapat diartikan lima teknik atau cara yang harus dimiliki seorang pemimpin guna menyelesaikan persoalan yang dihadapi. Selain itu Panca Upaya Sandhi juga dapat diartikan lima upaya dalam memimpin. Dalam Lontar Siwabuddha Gama Tattwa, Panca Upaya Sandhi diartikan sebagai lima macam usaha dan upaya yang harus dimiliki oleh seorang pemimpin untuk menghadapi dan menyelesaikan persoalan serta tantangan yang menjadi tanggung jawabnya. Adapun bagian-bagian dari Panca Upaya Sandi ini yaitu:

1. Maya, artinya seorang pemimpin perlu melakukan upaya dalam mengumpulkan data atau permasalahan yang masih belum jelas duduk perkaranya.

2. Upeksa, artinya seorang pemimpin harus meneliti dan menganalisis semua data-data tersebut dan mengkodifikasikan secara profesional dan proporsional.

3. Indra Jala, artinya seorang pemimpin harus bisa mencarikan jalan keluar dalam memecahkan persoalan yang dihadapi sesuai dengan hasil analisisnya tadi.

4. Vikrama, artinya seorang pemimpin harus melaksanakan semua upaya penyelesaian dengan baik sesuai dengan aturan yang telah ditetapkan.

5. Lokika, artinya seorang pemimpin harus mengedepankan pertimbangan-pertimbangan logis dalam menindak lanjuti penyelesaian permasalahan yang telah ditetapkan (Latra, 2017).

Penelitian ini memfokuskan pembahasan tentang bagaimana strategi kepemimpinan kepala sekolah di era revolusi industri 4.0 ini dengan berlandaskan konsep dalam agama Hindu yang disebut dengan Panca Upaya Sandhi. Kebaharuan penelitian ini dengan penelitianpenelitian sebelumnya adalah adanya konsep kearifan lokal yang berperan sebagai penyelaras dan pendukung strategi kepemimpinan kepala sekolah yang akan diterapkan sehingga hasil yang dicapai lebih optimal. Sejalan dengan era revolusi industri 4.0 dengan trennya otomatisasi 
dan pertukaran data ini, strategi kepemimpinan kepala sekolah juga harus disesuaikan dengan perkembangan teknologi dengan tetap berlandaskan konsep-konsep kearifan lokal yang ada sehingga tercipta keselarasan untuk menciptakan manajemen pendidikan yang lebih berkualitas.

\section{Metode}

Pendekatan yang digunakan dalam penelitian ini adalah pendekatan kualitatif. Subyek dalam penelitian adalah kepala sekolah, sedangkan obyek penelitian yaitu strategi kepemimpinan kepala sekolah yang dapat diterapkan dalam menghadapi revolusi industri 4.0 berlandaskan konsep panca upaya sandhi. Data yang dikumpulkan berupa jenis-jenis strategi kepemimpinan kepala sekolah yang relevan di era revolusi industri 4.0 dan konsep panca upaya sandhi sebagai landasan dalam menjalankan strategi kepemimpinan tersebut. Untuk menghimpun data yang relevan dengan topik atau masalah yang akan dibahas digunakan teknik studi kepustakaan. Studi pustaka merupakan teknik pengumpulan data dengan mencari informasi dari buku literatur, jurnal, peraturan, laporan penelitian, karangan ilmiah, media massa dan sumber-sumber tertulis baik cetak maupun elektronik (Mukhlasin, 2019). Tahapan analisis data dilakukan menggunakan teknik analisis model Miles dan Huberman yaitu mengadakan kegiatan reduksi data, penyajian data, serta penarikan kesimpulan/verifikasi data (Sugiyono, 2010).

\section{Hasil dan pembahasan}

\section{Hasil Penelitian}

Berdasarkan hasil analisis data terkait strategi kepemimpinan kepala sekolah yang dapat diterapkan di era revolusi industri 4.0 yaitu: 1) Strategi kepemimpinan yang berorientasi pada meningkatkan kualitas SDM dan pengadaan sarana prasarana utamanya dalam bidang TIK; 2) Strategi kepemimpinan yang open mind (terbuka); 3) Strategi kepemimpinan yang siap menghadapi ketidak terdugaan; 4) Strategi kepemimpinan yang bereaksi cepat terhadap perubahan yang ada; 5) Strategi kepemimpinan yang result oriented (berorientasi pada hasil) bukan procedure oriented (berorientasi pada proses); 6) Strategi kepemimpinan 4C yaitu critical thinking, creativity, communication, collaboration; dan 7) Strategi kepemimpinan yang mampu mengembangkan jiwa kewirausahaan. Untuk mengoptimalkan penerapan strategi kepemimpinan yang dipaparkan di atas dapat diselaraskan dan didukung dengan dilandasi filosofi Panca Upaya Sandhi yang terdiri dari Maya, Upeksa, Indra Jala, Vikrama, dan Lokika. Bagian-bagian dari Panca Upaya Sandhi tersebut bermakna bahwa hendaknya seorang pemimpin dalam mengambil keputusan selalu berlandaskan pada data yang relevan, data yang telah dianalisis dengan benar dan dikodifikasikan secara profesional dan proporsional, berusaha mencari jalan keluar berdasarkan hasil analisis tersebut dan berpegang pada aturan yang telah ditetapkan serta tetap mengedepankan pertimbangan-pertimbangan yang logis dalam menyelesaikan masalah.

\section{Pembahasan}

Kepemimpinan dalam pendidikan menjadi sangat penting karena kepemimpinan kepala sekolah memiliki pengaruh signifikan terhadap kualitas pendidikan. Beberapa hasil studi terbaru telah menunjukkan bahwa ada hubungan yang signifikan antara kemampuan kepemimpinan kepala sekolah dengan efektifitas sekolah.

Sebenarnya, dengan adanya kemampuan yang memadai dan strategi kepemimpinan yang sesuai, kepala sekolah pasti mampu mewujudkan sekolah yang efektif. Namun karena kendala dalam memahami dan mengimplementasikan strategi kepemimpinan pendidikan di sekolah, sekolah tidak begitu berhasil sebagai wadah pendidikan. Dengan demikian, harus ada strategi kepemimpinan yang tepat untuk dapat diimplementasikan oleh kepala sekolah ketika mengelola sekolah supaya efektif dan mencapai tujuan pendidikan.

Menjadi kepala sekolah harus melalui berbagai tahapan seleksi, mulai seleksi administratif, seleksi akademik, hingga harus lulus diklat calon kepala sekolah. Kepala sekolah 
disamping harus memimpin sekolah sesuai dengan tugas pokok dan fungsinya, juga harus mampu menyikapi dan beradaptasi terhadap berbagai dinamika yang berkembang dengan cepat di era revolusi industri 4.0 ini, misalnya dalam implementasi kurikulum, aturan Penerimaan Peserta Didik Baru, peningkatan kompetensi guru, peningkatan kompetensi kepala sekolah, dan sebagainya. Di zaman otonomi daerah saat ini, seorang kepala sekolah disamping harus mengamankan kebijakan pemerintah pusat, juga harus mengamankan kebijakan kepala daerah, bahkan secara politis, kadang pengaruh kebijakan kepala daerah lebih dominan daripada kebijakan pemeritah pusat, karena kepala sekolah diangkat dan ditempatkan oleh kepala daerah.

Saat ini dunia pendidikan dihadapkan pada sejumlah tantangan. Seorang kepala sekolah yang visioner tentunya memiliki kepekaan dan kecepatan dalam merespon atau menjawab tantangan tersebut. Di era revolusi industri 4.0 saat ini, masalah strategis yang banyak mendapatkan perhatian adalah, pentingnya meningkatkan mutu lulusan untuk bisa bersaing dalam dunia kerja. Walau sepintas hal tersebut identik dengan jenjang SMK, tetapi secara kebijakan, implementasi kurikulum 2013 yang menggantikan kurikulum 2006 bertujuan untuk meningkatkan mutu pendidikan sekaligus daya saing lulusan pada setiap jenjang.

Era revolusi industri 4.0 adalah sebuah era dimana pekerjaan sudah banyak dilakukan secara digital. Hanya dengan menggunakan satu perangkat, bisa digunakan untuk mengatur beberapa pekerjaan (multi tasking). Istilahnya tinggal sentuh layar, maka pekerjaan pun dapat dilakukan atau kebutuhan pun dapat terpenuhi. Saat ini banyak pekerjaan atau dokumen yang sudah serba elektronik, seperti e-KTP, e-passport, e-book, e-learning, e-ticket, e-banking, ecommerce, $e$-toll, dan sebagainya. Penguasaan TIK pun penting dikuasai oleh guru, karena TIK selain digunakan sebagai sarana belajar, juga menjadi salah satu sumber belajar, bahkan banyak sekali digunakan seiring dengan semakin meningkatkan kebutuhan terhadap penggunaan perangkat TIK. Guru jangan sampai gaptek alias gagap teknologi, karena tidak tertutup kemungkinan justru siswanya yang lebih piawai menggunakan perangkat TIK dibandingkan dengan gurunya.

Mengingat pentingnya penguasaan TIK dalam kegiatan pembelajaran, maka kepala sekolah perlu melakukan beberapa strategi dalam menjalankan kepemimpinan di era revolusi industri 4.0 ini. Pertama, peningkatan kompetensi guru dalam pemanfaatan TIK dalam pembelajaran. Kedua, pengadaan sarana dan prasana penunjang seperti laboratorium komputer, jaringan internet, sumber belajar, alat-alat peraga, dan media pembelajaran berbasis TIK. Ketiga, membuka kerjasama dengan perusahaan provider, atau operator TIK baik dalam bentuk kerjasama pelatihan atau penyediaan perangkat TIK. Disamping itu untuk menghadapi revolusi industri 4.0 menurut Joko Widodo (Al Alawi, 2018) harus diikuti pembangunan SDM yang besarbesaran dan tidak boleh setengah-setengah. Untuk itu, pertama dibutuhkan strategi kepemimpinan yang open mind (terbuka). Open mind maksudnya terbuka di segala bidang dan elemen yang ada di sekolah seperti keterbukaan anggaran, keterbukaan terhadap kritik dan masukan, keterbukaan terhadap permasalahan yang ada, keterbukaan terhadap seluruh elemen yang ada di sekolah baik itu siswa, guru, pegawai dan juga orang tua siswa serta masyarakat. Dengan keterbukaan apapun yang terjadi di sekolah akan diketahui secara transparan dan seluruh elemen sekolah akan merasa memiliki sehingga ada keinginan untuk memajukan sekolah. Kedua, hadirnya revolusi industri 4.0 membutuhkan pemimpin yang siap menghadapi ketidak terdugaan. Karena perubahan sangat cepat sekali, jangan sampai pemimpin terkagetkaget sehingga harus siap menghadapinya. Ketiga, pemimpin harus bereaksi cepat terhadap perubahan yang ada. Pasalnya perubahan sangat cepat sekali. Keempat pemimpin harus result oriented (berorientasi pada hasil) bukan procedure oriented (berorientasi pada proses). Terakhir pemimpin harus bisa berkolaborasi. Tidak bisa pemimpin bersikap tertutup. Harus bisa bicara dengan stakeholder tentang kesulitan dan masalah yang ditemui karena perubahan kedepan sangat cepat. Hadirnya revolusi industri 4.0 akan melahirkan reformis pembawa perubahan yang merespons cepat dengan sistem kerja dan regulasi sederhana.

Selain itu untuk dapat bertahan di era revolusi industri 4.0. menurut Dirjen Sumber Daya Iptek dan Dikti Kemenristekdikti Ali Ghufron Mukti (Ditjen Sumber Daya Iptek Dikti, 2018) seorang pemimpin harus bisa menerapkan strategi 4C untuk dapat tetap eksis di era industri 
generasi keempat ini. Formula 4C ini meliputi pertama, critical thinking, seorang pemimpin seyogyanya bersikap skeptis dan kritis, walaupun pintar tetapi jika pemimpin tidak kritis akan percuma dan stagnan. Kedua, creativity, yakni mampu melahirkan inovasi-inovasi baru. Seorang pemimpin harus mampu menciptakan hal-hal baru yang unik sebagai ciri khas organisasi untuk kemajuan organisasinya. Ketiga, communication, seorang pemimpin harus mampu mengkomunikasikan dengan baik segala informasi yang ada sehingga dapat diterima oleh anggota organisasi dan publik secara benar dan tidak menimbulkan kesalahpahaman. Disamping itu segala bentuk inovasi dan kemajuan yang diciptakan dan dicapai sekolah harus juga dipublikasikan untuk meningkatkan citra organisasi sekolah di mata masyarakat. Komunikasi seorang pemimpin memengaruhi keputusan orang lain untuk mengikuti atau tidak. Komunikasi yang meyakinkan menjadikan orang lain percaya dan mau mengikuti apa yang dikatakan seseorang (Komariah dkk, 2018). Keempat, collaboration, dengan kemampuan berkolaborasi atau kerjasama yang baik dari seorang pemimpin akan dapat memperkuat organisasi dan memecahkan permasalah yang ditemui. Misalnya di lingkungan sekolah seorang kepala sekolah dapat menjalin kerjasama dengan sekolah lain dalam pelaksanaan kegiatan pendidikan seperti pelatihan guru, sharing teknologi yang dimiliki masing-masing sekolah dan kerjasama lainnya yang relevan, ataupun kerjasama dengan pengguna lulusan sebagai contoh di jenjang sekolah SMK, sehingga lulusannya dapat cepat terserap dalam dunia kerja.

Di sekolah-sekolah tertentu ada yang menerapkan kebijakan pelarangan penggunaan HP di kalangan siswa dengan alasan rawan disalahgunakan. Upaya tersebut sebenarnya langkah preventif, tetapi seolah menjauhkan diri dari pemanfaatan TIK. Oleh karena itu, perlu ada kebijakan yang proporsional berkaitan dengan pemanfaatan TIK di kalangan siswa, misalnya siswa mengunakan HP hanya saat belajar yang memang membutuhkan untuk memanfaatkan HP, dan selain itu dilarang, karena HP dapat menjadi sarana sumber belajar. Internet saat ini sudah menjadi bagian dari gaya hidup masyarakat, termasuk siswa. Bahkan 24 jam, mulai bangun tidur sampai tidur lagi seseorang tidak dapat lepas dari koneksi internet. Melalui berbagai aplikasi yang diunduh dari play store, anak-anak juga bisa belajar dan melatih kreativitas mereka. Walau demikian, penggunaannya perlu didampingi oleh orang tua agar tidak salahgunakan. Sekolah-sekolah yang mengotimalkan TIK dalam layanan pendidikan dan pembelajaran akan menjadikan mereka sekolah unggul dan berkualitas. Para siswanya pun ada yang berhasil menjadi juara olimpiade atau membuat sebuah karya inovatif. Hal tersebut tentunya akan berdampak positif terhadap prestasi dan citra sekolah di mata masyarakat, karena saat ini masyarakat juga semakin kritis terhadap mutu sekolah.

Kepala sekolah sebagai pemimpin dan manajer sekolah memiliki kewenangan dalam pengembangan TIK di sekolah. Walau demikian, terbatasnya dana biasanya menjadi kendala klasik dalam mewujudkan hal tersebut. Oleh karena itu, kepala sekolah dituntut untuk memiliki jiwa kewirausahaan, pandai membuka jaringan dan kemitraan dengan berbagai pemangku kepentingan (stakeholder) seperti komite sekolah, dunia usaha dan industri, dan Lembaga Swadaya Masyarakat sebagai bentuk sinergi dalam melaksanakan program tersebut (Apandi, 2018).

Jika dibandingkan dengan penelitian-penelitian sebelumnya terkait dengan strategi kepemimpinan kepala sekolah, seperti penelitian yang dilakukan oleh Fakhrunnisa, R. (2019) dengan judul Strategi Kepemimpinan Kepala Sekolah dalam Pengembangan Profesionalisme Guru di SMK Negeri 2 Temanggung 2018/2019. Penelitian ini sama-sama memperoleh hasil bahwa strategi yang diterapkan salah satunya dalam peningkatan kualitas SDM yaitu Guru. Perbedaannya penelitian ini tidak hanya mencakup strategi kepemimpinan dalam pengembangan profesionalisme guru, tetapi lebih pada strategi bagaimana pengelolaan manajamen sekolah termasuk guru dengan berpedoman pada data yang baik dan logika yang benar. Penelitian yang dilakukan oleh Usman, dkk (2013) dengan judul Strategi Kepemimpinan Pembelajaran Menyongsong Implementasi Kurikulum 2013. Perbedaan penelitian ini dengan penelitian Usman, dkk adalah penelitian Usman, dkk lebih mefokuskan pada strategi kepemimpinan dalam proses pembelajaran, sedangkan penelitian ini berfokus pada strategi kepemimpinan terkait pengelolaan sekolah masa kini di era revolusi industri 4.0. Penelitian yang dilakukan oleh Yumawati (2019) dengan judul Strategi Kepemimpinan Kepala Sekolah 
dalam Meningkatkan Mutu Pendidikan SD Negeri 03 Sungayang. Penelitian ini sama-sama untuk mengetahui Strategi kepemimpinan kepala sekolah. Penelitian yang dilakukan oleh Yumawati menghasilkan strategi kepemimpinan yang berpedoman pada penyusunan perencanaan dan pengembangan sekolah dengan merumuskan visi, misi dan tujuan jangka pendek ( 1 tahun) dan tujuan jangka menengah ( 4 tahun) dimana pelaksanaan strateginya dilakukan dengan meningkatkan kedisiplinan, meningkatkan hasil Ujian Nasional setiap tahun, mengadakan kegiatan ekstrakurikuler, menjalin kerjasama yang baik dengan komite, wali murid, alumni dan lembaga-lembaga pemerintah terdekat, sedangkan hasil penelitian ini lebih menekankan pada strategi kepemimpinan kepala sekolah yang bergerak cepat dengan berorientasi pada hasil, bukan pada proses, tetapi memiliki persamaan dalam menjalin kerjasama/berkolaborasi dengan elemen-elemen yang terkait di sekolah maupun luar sekolah. Sejalan dengan penelitian ini, Sanjaya (2012) mengemukakan bahwa Dengan menerapkan gaya kepemimpinan yang dibutuhkan dalam sebuah lembaga atau organisasi, akan membawa lembaga tersebut pada kondisi stabil dan efektif. Akan tetapi, Sanjaya lebih menekankan pada adanya sinergitas antara pemimpin dengan bawahan demi tercapainya tujuan yang tertuang dalam visi dan misi lembaga.

Keefektifan strategi kepemimpinan kepala sekolah berkaitan dengan keadaan atau situasi. Apabila strategi kepemimpinan sesuai dengan situasi tertentu, strategi itu efektif, namun apabila strategi kepemimpinan tidak sesuai dengan situasi tertentu, strategi itu tidak efektif.

Dalam penerapan strategi kepemimpinan tersebut di lapangan tentunya tidak akan berjalan dengan mudah. Pasti ada saja permasalahan atau rintangan yang mungkin ditemui. Oleh karena itu, untuk dapat meminimalkan permasalahan yang mungkin ditemui, seorang kepala sekolah dapat menyelaraskan strategi kepemimpinan yang diterapkan dengan konsep Panca Upaya Sandhi sebagai upaya untuk memperkuat strategi kepemimpinan dan untuk meminimalkan persoalan-persoalan yang menjadi tanggung jawab kepala sekolah.

Berdasarkan uraian yang telah dipaparkan di atas dapat dirangkum bahwa setiap strategi kepemimpinan yang diterapkan pada era revolusi industri 4.0 yang selaras dengan konsep Panca Upaya Sandhi hendaknya selalu berlandaskan pada data yang relevan, data yang telah dianalisis dengan benar dan dikodifikasikan secara profesional dan proporsional, berusaha mencari jalan keluar berdasarkan hasil analisis tersebut dan berpegang pada aturan yang telah ditetapkan serta tetap mengedepankan pertimbangan-pertimbangan yang logis dalam menyelesaikan masalah. Dengan demikian diharapkan keputusan yang diambil oleh seorang kepala sekolah dapat dipertanggungjawabkan dengan baik dan apa yang menjadi tujuan sekolah dapat tercapai.

\section{Simpulan dan saran}

Berdasarkan pembahasan yang telah dipaparkan sebelumnya simpulan dari penelitian ini yaitu, strategi kepemimpinan kepala sekolah di era revolusi industri 4.0 yang dapat diterapkan oleh kepala sekolah meliputi strategi kepemimpinan yang berorientasi pada peningkatan kualitas SDM dan peningkatan pengadaan sarana prasarana utamanya dalam bidang TIK, kepemimpinan yang open mind (terbuka), kepemimpinan yang siap menghadapi ketidak terdugaan, kepemimpinan yang harus bereaksi cepat terhadap perubahan yang ada, kepemimpinan yang result oriented (berorientasi pada hasil) bukan procedure oriented (berorientasi pada proses), kepemimpinan dengan menerapkan formula 4C yaitu critical thinking, creativity, communication, collaboration, dan kepemimpinan yang mampu mengembangkan jiwa kewirausahaan. Strategi kepemimpinan yang diterapkan ini akan lebih optimal jika diselaraskan dengan konsep Panca Upaya Sandhi yang terdiri dari maya, upeksa, indra jala, vikrama dan lokika, dimana setiap strategi kepemimpinan yang diterapkan jika berlandaskan pada data yang relevan, data yang telah dianalisis dengan benar, dan dikodifikasikan secara profesional dan proporsional, berusaha mencari jalan keluar berdasarkan hasil analisis tersebut dan berpegang pada aturan yang telah ditetapkan serta tetap mengedepankan pertimbangan-pertimbangan yang logis dalam menyelesaikan masalah maka diharapkan keputusan yang diambil oleh seorang kepala sekolah dapat dipertanggung jawabkan dengan baik dan apa yang menjadi tujuan sekolah dapat tercapai. 
Saran yang dapat disampaikan bagi kepala sekolah dalam penelitian ini yaitu berbagai strategi kepemimpinan kepala sekolah di era revolusi industri 4.0 agar dapat diterapkan dengan tetap memperhatikan situasi, kondisi dan kearifan lokal yang ada di lingkungan sekolah yang dipimpin, sehingga tidak terkesan warga sekolah terpaksa dan tidak ikhlas untuk menjalankannya. Perlu adanya penyamaan persepsi dan komitmen antara kepala sekolah dengan semua elemen yang ada di sekolah dalam penerapan strategi kepemimpinan kepala sekolah sehingga dalam pelaksanaannya mendapat dukungan penuh dari warga sekolah dan apa yang menjadi tujuan sekolah dapat tercapai dengan cepat dan tepat sesuai target yang telah ditetapkan.

\section{Daftar Rujukan}

Al Alawi, M. (2018). Tipe Pemimpin yang Mampu Hadapi Revolusi Industri 4.0 Menurut Jokowi. Kamis, 29 November. Retrieved from https://regional.kompas.com/read/2018/11/29/05531001/tipe-pemimpin-yang-mampuhadapi-revolusi-industri-40-menurut-jokowi

Apandi, I. (2018). Kepala Sekolah Inovatif dan Visioner di Era Revolusi Industri 4.0. 8 Desember. Retrieved from https://www.kompasiana.com/idrisapandi/5c0b431bbde57540ec66d978/kepalasekolah-inovatif-dan-visioner-di-era-revolusi-industri-4-0

Ditjen Sumber Daya Iptek Dikti. (2018). Formula 4C untuk Bertahan pada Era Revolusi Industri 4.0. Retrieved November 8, 2019, from Sumber Daya Riset Dikti website: http://sumberdaya.ristekdikti.go.id/index.php/2018/05/04/formula-4c-untuk-bertahanpada-era-revolusi-industri-4-0/

Fakhrunnisa, R. (2019). Strategi Kepemimpinan Kepala Sekolah Dalam Pengembangan Profesionalisme Guru Di SMK Negeri 2 Temanggung 2018/2019 (Universitas Muhammadiyah Surakarta). Retrieved from http://eprints.ums.ac.id/69461/11/NASKAH PUBLIKASI.pdf

Haris, A. (2018). Kepemimpinan Pendidikan (Teori, Studi Kasus \& Aplikasi) (1st ed.). Bandung: CV. Alfabeta.

Komariah, A., \& dkk. (2018). Kepemimpinan Autentik Riset Implementasi Manajemen Perubahan (1st ed.). Bandung: CV. Alfabeta.

Latra, I. W. (2017). Politik dalam Perspektif Hindu. Retrieved from https://simdos.unud.ac.id/uploads/file_penelitian_1_dir/45be662ce3fcc318cecbcc75c365 ce5f.pdf

Mukhlasin, A. (2019). Kepemimpinan Pendidikan Di Era Revolusi Industri 4.0. Jurnal Tawadhu, 3(1), 674-692. https://doi.org/10.13140/RG.2.2.30831.59043

Rusdianto, E. (2019). Kepemimpinan dalam Dunia Pendidikan di Indonesia di Era Revolusi Industri 4.0. Retrieved from https://www.academia.edu/38803096/kepemimpinan_dalam_dunia_pendidikan_di_Indon esia_di_era_revolusi_industri_4.0.

Sanjaya, Putu. 2012. Pentingnya Kepemimpinan Dan Kemampuan Manajerial Untuk Peningkatan Mutu Lembaga Pendidikan. Jurnal Penjaminan Mutu, 1(1): 127-138.

Sriwahyuni, E., Kristiawan, M., \& Wachidi, W. (2019). Strategi Kepala Sekolah Dalam Mengimplementasikan Standar Nasional Pendidikan (SNP) Pada SMK Negeri 2 Bukittinggi. JMKSP (Jurnal Manajemen, Kepemimpinan, dan Supervisi Pendidikan), 4(1), 21-33.

Sugiyono. (2010). Metode Penelitian Pendidikan Pendekatan Kuantitatif, Kualitatif, dan R\&D (10th ed.). Bandung: CV. Alfabeta.

Suriansyah, A., \& Aslamiah. (2015). Strategi Kepemimpinan Kepala Sekolah, Guru, Orang Tua, Dan Masyarakat Dalam Membentuk Karakter Siswa. Jurnal Cakrawala Pendidikan, 34(2), 234-247.

Usman, H., Nuryadin, D., \& Raharjo, E. (2013). Strategi Kepemimpinan Pembelajaran Menyongsong Implementasi Kurikulum 2013. Jurnal Cakrawala Pendidikan, 32(1).

Wahyudi. (2015). Kepemimpinan Kepala Sekolah Dalam Organisasi Pembelajar (Learning 
Organization) (4th ed.). Bandung: CV. Alfabeta.

Wulandari, F., \& dkk. (2019). Kepemimpinan Kepala Sekolah di Era Revolusi Industri 4.0 dalam Meningkatkan Akreditasi Sekolah. Prosiding Seminar Nasional Pendidikan Program Pascasarjana Universitas PGRI Palembang, 308-312. Retrieved from https://jurnal.univpgri-

palembang.ac.id/index.php/Prosidingpps/article/download/2539/2366

Yulmawati. (2016). Strategi Kepemimpinan Kepala Sekolah Dalam Meningkatkan Mutu Pendidikan SD Negeri 03 Sungayang. Jurnal Manajemen, Kepemimpinan, dan Supervisi Pendidikan, 1(2), 109-121. 